\title{
Interdiffusion Behaviour of NiCoCrAlY Coating and N5 Single Crystal Superalloy
}

\author{
Jiaxu Cao ${ }^{1,2}$, Yingkun Liu ${ }^{1,2}$, Chunming Deng ${ }^{2, * \mathbb{D}}$, Kun Yang ${ }^{2}$ and Feng $\mathrm{Li}^{1}$ \\ 1 School of Materials and Energy, Guangdong University of Technology, Guangzhou 510006, China; \\ vikkycool767158226@163.com (J.C.); lingling_014@163.com (Y.L.); fengli@gdut.edu.cn (F.L.) \\ 2 The Key Lab of Guangdong for Modern Surface Engineering Technology, National Engineering Laboratory \\ for Modern Materials Surface Engineering Technology, Guangdong Institute of New Materials, \\ Guangzhou 510651, China; yangkun@gdinm.com \\ * Correspondence: dengchunming@gdinm.com
}

Received: 24 February 2020; Accepted: 13 April 2020; Published: 16 April 2020

\begin{abstract}
This paper aims at investigating the microstructure and phases evolution of single crystal superalloy/high temperature protective coating during high temperature static oxidation, and exploring the influence of element interdiffusion behaviour on microstructure and phase evolution of the single crystal superalloy substrate. A NiCoCrAlY high-temperature protective coating was deposited on the Ni-based single-crystal superalloy by low-pressure plasma spraying technology. The coated samples were subjected to static oxidation for $200 \mathrm{~h}$ at a constant temperature of $1100^{\circ} \mathrm{C}$. Scanning electron microscope, energy dispersive spectrometer and X-ray diffraction were used to characterise the microstructure and phase after interdiffusion between the coating and the substrate at high temperature. The results showed that a dense thermally grown oxide layer was formed on the surface of the NiCoCrAlY coating after oxidation for over $100 \mathrm{~h}$. The only interdiffusion zone was formed after oxidation for $50 \mathrm{~h}$, while both interdiffusion zone and secondary reaction zone could be observed after oxidation for over $100 \mathrm{~h}$. The thickness of interdiffusion zone and secondary reaction zone is increased with the extension of oxidation time, and the grain growth of topological close-packed phase in the secondary reaction zone is found. $\mathrm{Al}, \mathrm{Cr}$ and $\mathrm{Co}$ in the coating diffuse from the coating to the substrate, while Ni and refractory materials like Ta, Mo, Re and W diffuse from the coating to the substrate. The interdiffusion of coating and substrate leads to the instability of $\gamma / \gamma^{\prime}$ phase in the substrate, which finally results in the formation of $\mathrm{W}, \mathrm{Re}$ and Cr-rich needle-like topological close-packed phase in the substrate.
\end{abstract}

Keywords: single crystal superalloy; NiCoCrAlY coating; static oxidation; interdiffusion

\section{Introduction}

As the main materials used for advanced aero-engine blades, Ni-based single crystal superalloys possess excellent creep strength and fatigue resistance performance at high service temperature [1-5]. In contrast, the oxidation resistance of Ni-based single crystal superalloys is poor for the increased service temperature in high thrust-ratio turbine engines, and one of the most effective ways is to apply with protective coatings like MCrAlY, PtAl coating [6-10]. MCrAlY coatings ( $\mathrm{M}$ is generally $\mathrm{Ni}, \mathrm{Co}$ or $\mathrm{Ni}$ and $\mathrm{Co}$ ) have good compatibility with single crystal superalloys at high temperature. Simultaneously, the sufficient content of $\mathrm{Cr}$ and $\mathrm{Al}$ in the coating ensure its oxidation and hot corrosion resistance [11-14].

However, the huge differences in composition between coating and underlying substrate can lead to element interdiffusion during long-term high-temperature service, resulting in the segregation of insoluble elements such as Ta in the substrate and the precipitation of harmful topological close-packed 
phase [15-17]. The main components of topological close-packed phases are W, Mo and Re, which are added in the superalloy for strengthening the comprehensive performance of superalloys at high temperature [18-20]. There is no doubt that the precipitation of harmful topological close-packed phases will not only deplete the refractory reinforcing elements in the substrate but also be the source of rack propagation, resulting in the system failure [21,22]. Up to now, few reports are available on the precipitation of topological close-packed phases during high temperature oxidation process. In order to obtain a higher quality coated surface, many researchers have carried out related research, for example, Fernande-Abia proposed a mechanistic model for cutting forces in turning with nose radius tools [23-26]. In addition, generally MCrAlY coatings were widely deposited on superalloy by thermal spray technology including low-pressure plasma spraying, air plasma spraying and high velocity oxy/air fuel, physical vapor deposition and electron beam-physical vapor deposition, depending on the coating technical requirements. Low-pressure plasma spraying is the most widely used and successful process for the high coating performance especially for blade of aero-engine because of the shrouded Ar environment and relatively low working pressure. However, few studies focusing on interdiffusion between low-pressure plasma-sprayed MCrAlY coatings and single crystal superalloy was found, which is still insufficient to understand the mechanism of interdiffusion between Ni-based superalloy (especially the single crystal superalloys) and protective MCrAlY coatings [27-30].

In this paper, the interdiffusion behaviour of N5 single crystal superalloy/NiCoCrAlY coating are investigated during high-temperature static oxidation process. The microstructure evolution, interdiffusion of elements and precipitation of characteristic phase are studied after static oxidation respectively. The research is helpful for the understanding of interdiffusion behaviour between LPPS sprayed protective MCrAlY coatings and single crystal superalloy, the precipitation process of the precipitated phase as well, which will provide a certain guideline for the estimation of service life of superalloy.

\section{Experimental Procedure}

N5 Ni-based single crystal superalloy and NiCoCrAlY is used as substrate and protective coating respectively, and their chemical compositions are shown in Table 1. The substrate was cut into sheet-shaped blocks with a dimension of $100 \mathrm{~mm} \times 15 \mathrm{~mm} \times 2.5 \mathrm{~mm}$ by electric discharge machining. Prior to thermal spraying, the substrate was grit-blasted at a pressure of $0.3-0.5 \mathrm{MPa}$ using 120\# white fused alumina. A low-pressure plasma spraying device (Oerlikon Metco, Freienbach, Switzerland) was used to deposit NiCoCrAlY coating on the substrate. The deposition parameters are shown in Table 2. The coated sample was cut into a dimension of $10 \mathrm{~mm} \times 15 \mathrm{~mm} \times 2.5 \mathrm{~mm}$ with a Secotom- 15 precision cutting machine for static oxidation test.

Table 1. Nominal compositions of N5 single crystal superalloy and NiCoCrAlY coating.

\begin{tabular}{ccc}
\hline Component (wt \%) & N5 Single Crystal & NiCoCrAlY Coating \\
\hline $\mathrm{Ni}$ & Balance & 31.41 \\
$\mathrm{Co}$ & $7-9$ & 38.40 \\
$\mathrm{Cr}$ & $6-8$ & 19.73 \\
$\mathrm{Al}$ & $6-8$ & 10.44 \\
$\mathrm{Mo}$ & $2-4$ & - \\
$\mathrm{Ta}$ & $6-8$ & - \\
$\mathrm{Re}$ & $3-4$ & - \\
$\mathrm{Y}$ & - & 0.01 \\
$\mathrm{~W}$ & $4-6$ & - \\
\hline
\end{tabular}


Table 2. Deposition parameters of NiCoCrAlY coating prepared by low pressure plasma spraying.

\begin{tabular}{cc}
\hline Parameters & LPPS \\
\hline Pressure $(\mathrm{Pa})$ & 40 \\
Current $(\mathrm{A})$ & 1800 \\
Power $(\mathrm{kW})$ & 126 \\
Plasma gas (Ar) (slpm) ${ }^{\mathrm{a}}$ & 110 \\
${\text { Plasma gas }(\mathrm{He})(\mathrm{slpm})^{\mathrm{a}}}^{\mathrm{a}}$ & - \\
${\text { Plasma gas }\left(\mathrm{H}_{2}\right)(\mathrm{slpm})^{\mathrm{a}}}^{-1}$ Powder feed rate $\left(\mathrm{g} \cdot \mathrm{min}^{-1}\right)$ & 6 \\
Spraying distance $(\mathrm{mm})$ & 30 \\
Torch speed $(\mathrm{mm} / \mathrm{s})^{\text {a SLPM: standard litres per minute. }}$ & 350 \\
\hline
\end{tabular}

Then, the constant temperature static oxidation test was performed in a muffle furnace (KSF1400, kilns, Shanghai, China). The NiCoCrAlY coated/N5 single crystal superalloy samples and the uncoated samples were placed in an Alumina crucible at $1100^{\circ} \mathrm{C}$ (Air, $1 \mathrm{~atm}$ ). After a predetermined oxidation time $(0,50,100,200 \mathrm{~h})$, the sample is taken out for the characterizations.

The X-ray diffractometer (D8-Advance, Bruker, Karlsruhe, Germany) was used to analyse the phase of the coating using $\mathrm{Cu} \mathrm{K} \alpha$-ray as the diffraction source with a scanning step of $0.02^{\circ} / \mathrm{s}$ and a scanning range of $2 \theta$ from $10^{\circ}$ to $90^{\circ}$. Field emitting-scanning electron microscope (FE-SEM, Nava-Nano-430, FEI, Hillsboro, OR, USA) equipped with energy spectrum (EDS, Oxford INCAx-sight 6427, Oxford, UK) were used to analyse the morphology and chemical compositions of coating and substrate.

\section{Results and Discussions}

\subsection{LPPS Sprayed NiCoCrAlY Coating on N5 Single Crystal Superalloy}

Figure 1 presents the morphology and XRD pattern of the as-deposited coating prepared by low-pressure plasma spraying technology (LPPS). The cross-sectional image of the coating shows a laminar microstructure, typically for thermal spray coating. The coating had an average thickness of $60 \mu \mathrm{m}$ and a density of over $99 \%$. The coating was well bonded with the grit-blasted substrate, and a distinct interface of coating/substrate was observed. No significant oxide region was observed in the LPPS coating. According to the XRD pattern, the main phase of the as-deposited coating consists of $\gamma-\mathrm{Ni} / \gamma^{\prime}-\mathrm{Ni}_{3} \mathrm{Al}[31]$.
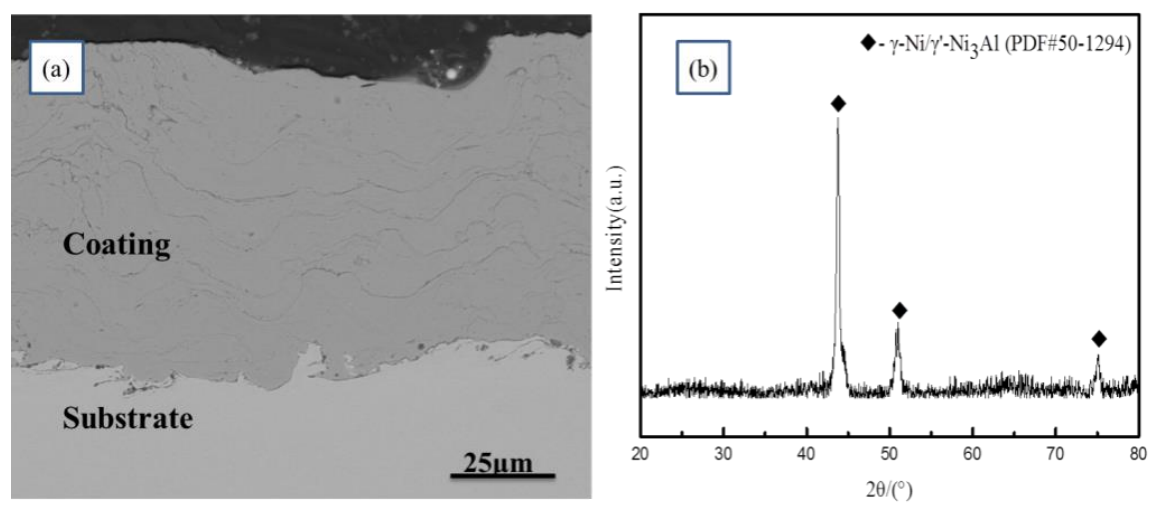

Figure 1. Cross-sectional back-scattered electron (BSE) image and X-ray diffraction (XRD) diagram of as-deposited coating: (a) cross-sectional BSE-images, (b) XRD diagram.

\subsection{Static Oxidation of NiCoCrAlY Coated N5 Single Crystal Superalloy}

Figure 2 shows the enlarged BSE images of the thermally grown oxide (TGO) layer after static oxidation of coating at $1100{ }^{\circ} \mathrm{C}$ for different time. After static oxidation for $50 \mathrm{~h}$, a $2.20 \mu \mathrm{m}$ TGO layer 
appeared on the coating, and the TGO is $\mathrm{Cr}_{2} \mathrm{O}_{3}$ and $\mathrm{NiCr}_{2} \mathrm{O}_{4}$ according to the XRD result. With the extension of the oxidation time to $100 \mathrm{~h}$ and $200 \mathrm{~h}$, the thickness of TGO layer is gradually increased to be 3.75 and $4.34 \mu \mathrm{m}$. However, the TGO layer is composed of 2 layers, including the spinel $\mathrm{Ni}(\mathrm{Cr}, \mathrm{Al})_{2} \mathrm{O}_{4}$ top layer and $\alpha-\mathrm{Al}_{2} \mathrm{O}_{3}$ bottom layer after oxidation for 100 and $200 \mathrm{~h}$. During the oxidation process, the $\mathrm{Al}$ in the coating diffuses outward and the $\mathrm{O}$ from the surrounding atmospheric environment diffuses inward, and $\theta-\mathrm{Al}_{2} \mathrm{O}_{3}$ is firstly formed on the coating surface except the former spinel oxide, afterwards $\theta-\mathrm{Al}_{2} \mathrm{O}_{3}$ undergoes phase transformation into stable and dense equiaxed crystal $\alpha-\mathrm{Al}_{2} \mathrm{O}_{3}$ at $1100{ }^{\circ} \mathrm{C}$. The surface morphologies for bare and coated substrate oxidized at $1100{ }^{\circ} \mathrm{C}$ for $200 \mathrm{~h}$ are shown in Figure 3. For bare substrate, some relatively loose oxides with spinel structure are observed, while very dense oxide is formed on the coated substrate. Dense $\alpha-\mathrm{Al}_{2} \mathrm{O}_{3}$ at the bottom of TGO can effectively prevent the diffusion of external gases into the interior of the coating/substrate, therefore increasing the service life of the coating/single crystal superalloy significantly [32].
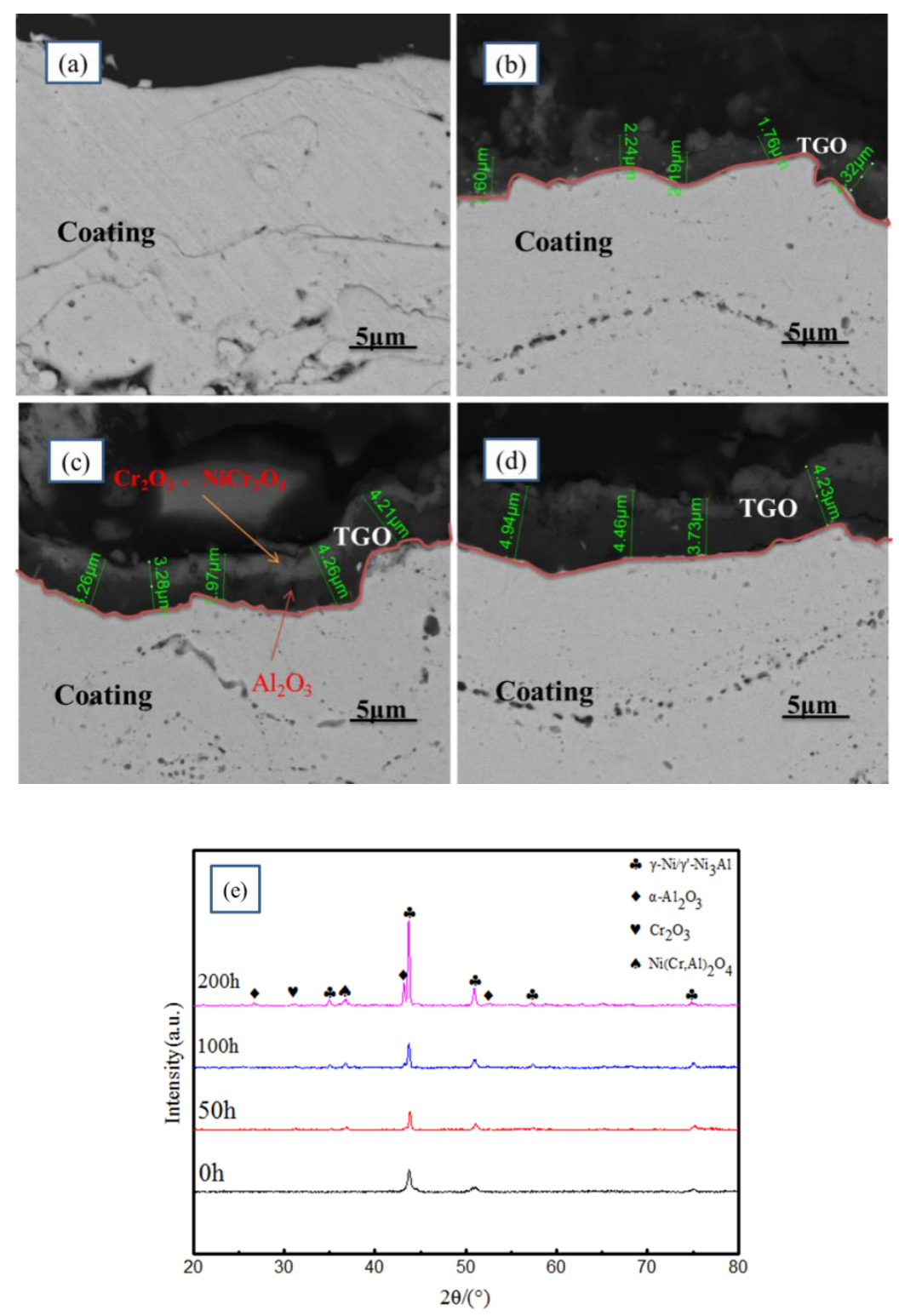

Figure 2. BSE images and XRD patterns of NiCoCrAlY coating after static oxidation at $1100{ }^{\circ} \mathrm{C}$ for different time: (a) 0 h; (b) 50 h; (c) 100 h; (d) 200 h; (e) XRD patterns. 

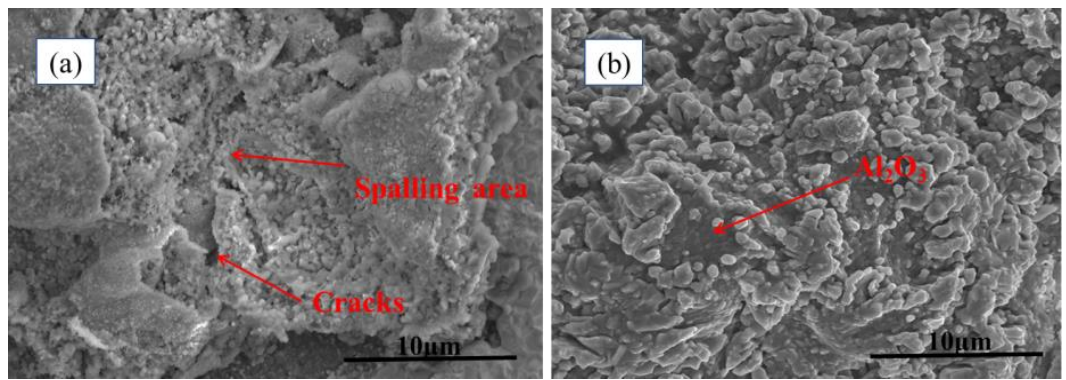

Figure 3. SEM images of sample surface after static oxidation at $1100{ }^{\circ} \mathrm{C}$ for $200 \mathrm{~h}$ : (a) bare substrate; (b) coated substrate.

\subsection{Interdiffusion Behaviour between NiCoCrAlY Coating and N5 Single Crystal Superalloy}

Figure 4 presents the cross-sectional morphology of NiCoCrAlY coating/N5 single crystal superalloy after static oxidation at $1100{ }^{\circ} \mathrm{C}$ for $0,50,100$ and $200 \mathrm{~h}$. Generally the $\mathrm{Al}$ in the coating will diffuse into the substrate because of the high concentration of $\mathrm{Al}$ in the coating, resulting in the following phase transformation in the substrate [33]:

$$
\begin{gathered}
3 \gamma-\mathrm{Ni}+[\mathrm{Al}] \rightarrow \gamma^{\prime}-\mathrm{Ni}_{3} \mathrm{Al}, \\
\gamma^{\prime}-\mathrm{Ni}_{3} \mathrm{Al}+2[\mathrm{Al}] \rightarrow 3 \beta-\mathrm{NiAl} .
\end{gathered}
$$

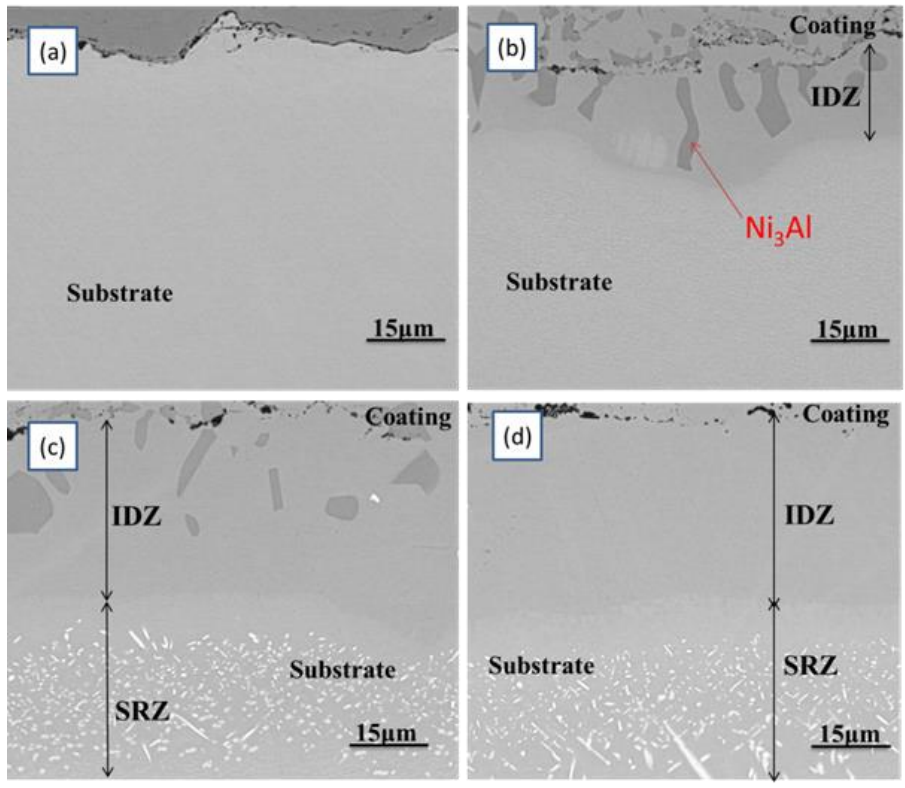

Figure 4. Cross-section of NiCoCrAlY coating/N5 single crystal superalloy after static oxidation at $1100{ }^{\circ} \mathrm{C}$ for different time: (a) $0 \mathrm{~h}$; (b) $50 \mathrm{~h}$; (c) $100 \mathrm{~h}$; (d) $200 \mathrm{~h}$.

According to the above-mentioned phase transformation process, after static oxidation for $50 \mathrm{~h}$, an interdiffusion zone (IDZ) with a thickness of $17 \mu \mathrm{m}$ was first formed at the coating/substrate interface, and the dark phase in the IDZ was the $\gamma^{\prime}-\mathrm{Ni}_{3} \mathrm{Al}$ phase, while the secondary reaction zone (SRZ) was not found. However, as the oxidation continued to be $100 \mathrm{~h}$, the content of $\gamma^{\prime}-\mathrm{Ni}_{3} \mathrm{Al}$ phase in IDZ was decreased, and a SRZ with a large amount of granular TCP phases also began to appear in the raft $\gamma$ 'substrate. The diffusion after $200 \mathrm{~h}$ oxidation is similar to that after $100 \mathrm{~h}$ oxidation, and the difference lies in more TCP content and larger TCP crystal in the SRZ with the extension of oxidation time. The thickness of IDZ and SRZ is also significantly affected by the oxidation time, as shown in Figure 5. It can be seen that the thickness of IDZ and SRZ is sharply increased during the oxidation 
process from $0 \mathrm{~h}$ to $100 \mathrm{~h}$, but the growth rate for both zones is obviously slowed down in the next $100 \mathrm{~h}[34,35]$.

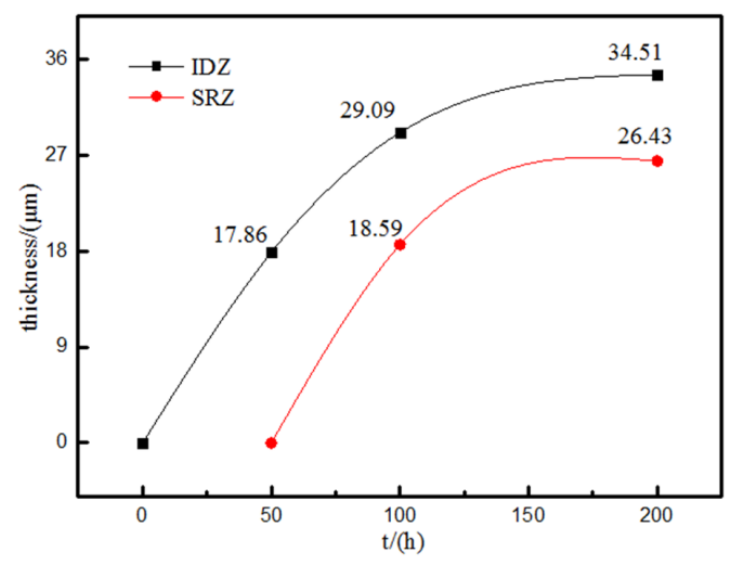

Figure 5. Variation of interdiffusion zone (IDZ) and secondary reaction zone (SRZ) for NiCoCrAlY coating/N5 single crystal superalloy with static oxidation time at $1100{ }^{\circ} \mathrm{C}$.

In order to analyse the interdiffusion behaviour, the distribution of elements was characterised using EDS every $5 \mu \mathrm{m}$ from coating sub-surface ( $20 \mu \mathrm{m}$ away to coating surface) to the interior substrate after oxidation for different time, as presented in Figure 6. In the as-deposited NiCoCrAlY coating on $\mathrm{N} 5$ single crystal superalloy, the content of $\mathrm{Al}, \mathrm{Cr}, \mathrm{Co}$, and $\mathrm{Ni}$ is $10.44 \mathrm{wt} \%, 19.73 \mathrm{wt} \%, 38.40 \mathrm{wt} \%$, and $31.41 \mathrm{wt} \%$ in the coating and $7.13 \mathrm{wt} \%, 7.31 \mathrm{wt} \%, 7.93 \mathrm{wt} \%$, and $60.27 \mathrm{wt} \%$ in the substrate, respectively. From Figure $6 \mathrm{a}$, the concentration of elements ranged between coating and substrate, indicating the interdiffusion had occurred after oxidation for $50 \mathrm{~h}$. In addition to being selectively oxidized, $\mathrm{Al}, \mathrm{Cr}$ and $\mathrm{Co}$ in the coating diffused into the substrate at the same time, leading to the gradual decrease of $\mathrm{Al}, \mathrm{Cr}$ and $\mathrm{Co}$ in the coating with the lapse of oxidation time, while Ni diffuses from the substrate to the coating according to the concentration profiles after oxidation for different time. Moreover, Mo, W, Ta and Re elements were also detected in the coating according to Figure $6 \mathrm{~b}-\mathrm{d}$, indicating that these elements diffuse into the coating. It is worth noting that the concentration fluctuation of $\mathrm{Ni}, \mathrm{Cr}$ and $\mathrm{Co}$ at the IDZ is connected with the precipitation phase.
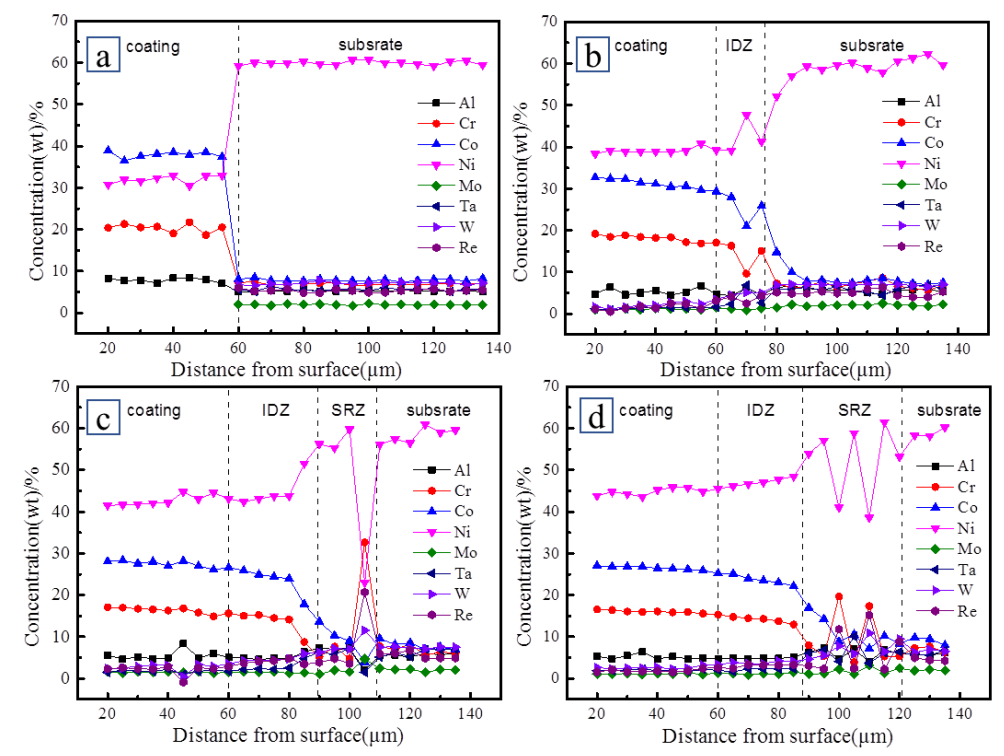

Figure 6. Energy dispersive spectrometer (EDS) elemental concentration profiles of NiCoCrAlY coating/N5 single crystal superalloy with depth from coating to substrate after static oxidation at $1100{ }^{\circ} \mathrm{C}$ : (a) $0 \mathrm{~h}$; (b) $50 \mathrm{~h}$; (c) $100 \mathrm{~h}$; (d) $200 \mathrm{~h}$. 


\subsection{Precipitation of TCP}

Formation of needle-like fragile TCP phase has significantly negative effect on the high temperature performance, such as high temperature strength, creep, etc. As mentioned before, with the extension of oxidation time, more TCP phases were precipitated and growth, which is verified from Figure 7. The size of the TCP phase is nearly doubled after oxidation from 100 to $200 \mathrm{~h}$, and the bright core region and the grey shell region can be clearly observed in Figure $7 \mathrm{~b}$. The needle-like TCP phase was oriented at $45^{\circ}$ or $135^{\circ}$ with the substrate. EDS revealed that TCP phase was rich in Cr and Re, as shown in Figure $7 \mathrm{c}, \mathrm{d}$. This is consistent with $\sigma$-TCP phase in nickel-based superalloy $[36,37]$.
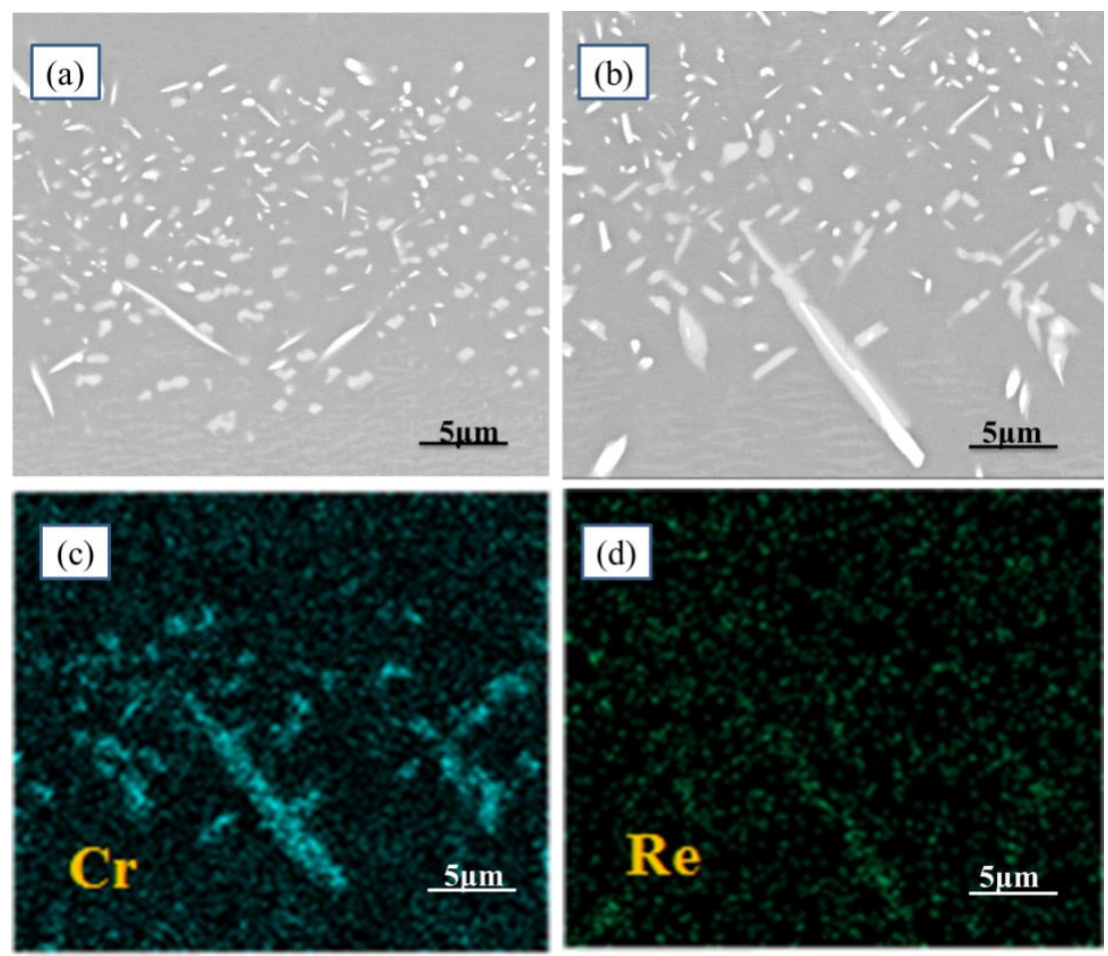

Figure 7. Cross-sectional BSE images and EDS element maps of precipitation phase: (a) $100 \mathrm{~h}$, (b) $200 \mathrm{~h}$,

(c) EDS Cr distribution in Figure b, (d) EDS Re distribution in Figure (b).

The chemical compositions for the core region and the shell region of $\sigma$-TCP phase were measured by EDS. It is found that the content of Ta, W and Re was $3.14 \mathrm{wt} \%, 16.14 \mathrm{wt} \%$ and $20.53 \mathrm{wt} \%$ in the bright core region, and the content of $\mathrm{Cr}$, Mo and Re was $40.15 \mathrm{wt} \%, 4.56 \mathrm{wt} \%, 28.92 \mathrm{wt} \%$ in the grey shell region. Therefore the precipitation of the TCP phase consumes a large amount of solid solution strengthening elements such as $\mathrm{Ta}, \mathrm{Mo}, \mathrm{W}$, Re; this is the reason for the decrease of high temperature creep properties of the single crystal superalloys after applying protective coatings. Both $\mathrm{Al}$ and $\mathrm{Cr}$ in the coating diffuse into the substrate during high temperature oxidation process, while the solid solution of both elements varies greatly. For $\mathrm{Al}$, it forms $\gamma^{\prime}-\mathrm{Ni}_{3} \mathrm{Al}$ and $\beta-\mathrm{NiAl}$ with $\mathrm{Ni}$ in the substrate depending on the concentration of Al during the diffusion. However the solid solubility of $\mathrm{Cr}$ in the Ni-based superalloy is much lower than that of $\mathrm{Al}, \alpha-\mathrm{Cr}$ is easily precipitated in the substrate during the diffusion process. While the refractory elements such as $\mathrm{W}$ and Re have much higher solid solubility in $\alpha-\mathrm{Cr}$ than $\mathrm{Al}$, Re will hasten the precipitation of $\alpha-\mathrm{Cr}$. As a whole, the interdiffusion of coating and substrate leads to the instability of $\gamma / \gamma^{\prime}$ phase in the substrate, which finally results in the formation of W, Re and Cr-rich needle-like TCP phase [38,39]. 


\section{Conclusions}

The NiCoCrAlY high-temperature protective coating was deposited on the Ni-based single-crystal superalloy by low-pressure plasma spraying technology. The microstructure and phase evolution of single crystal superalloy/high temperature protective coating during high temperature static oxidation, and the influence of element interdiffusion behaviour on microstructure and phase evolution of single crystal superalloy substrate were investigated systematically. Some important conclusions can be drawn as follows:

- The N5 Ni-based superalloy/NiCoCrAlY coating forms a dense $\alpha-\mathrm{Al}_{2} \mathrm{O}_{3}$ TGO, which can significantly improve the oxidation resistance performance of substrate.

- IDZ appears after static oxidation for $50 \mathrm{~h}$, then SRZ enriched with TCP phase will be observed at $100 \mathrm{~h}$, afterwards the TCP phase will gradually grow with the extension of the oxidation time.

- $\mathrm{Al}, \mathrm{Cr}$ and $\mathrm{Co}$ in the coating diffuses from the coating to the substrate, while Ni and refractory materials like Ta, Mo, Re and $\mathrm{W}$ diffuse from the coating to the substrate.

- The interdiffusion of coating and substrate leads to the instability of $\gamma / \gamma^{\prime}$ phase in the substrate, which finally results in the formation of $\mathrm{W}$, Re and $\mathrm{Cr}$-rich needle-like TCP phase. The concentration change law and the precipitation process of precipitation phase are of great significance to improve the reliability of the coating/single crystal superalloy system and reasonably predict its life.

Author Contributions: Conceptualization, J.C., C.D., K.Y. and F.L.; methodology, J.C. and C.D.; software, J.C., C.D. and Y.L.; validation, J.C. and C.D.; formal analysis, J.C. and C.D.; investigation, J.C. and C.D.; resources, J.C., C.D. and K.Y.; data curation, J.C., C.D. and Y.L.; writing-original draft preparation, J.C. and C.D.; writing-review and editing, J.C. and C.D.; funding acquisition, C.D., K.Y. and F.L. All authors have read and agreed to the published version of the manuscript.

Funding: This work was supported by the Guangdong Provincial Key Area Research and Development Program (No. 2019B010936001), the Guangdong Provincial Natural Science Foundation Project (No. 2016030312015, No. 2020A1515010948), and the Guangdong Academy of Sciences Project (No. 2020GDASYL-20200104028).

Conflicts of Interest: The authors declare no conflict of interest.

\section{References}

1. Rettberg, L.H.; Laux, B.; He, M.Y. Growth stresses in thermally grown oxides on Nickel-Based Single-Crystal alloys. Metall. Mater. Trans. 2016, 47, 1132-1142. [CrossRef]

2. Yuan, K.; Peng, R.L.; Li, X.H. Some aspects of elemental behaviour in HVOF MCrAlY coatings in high-temperature oxidation. Surf. Coat. Techol. 2015, 261, 86-101. [CrossRef]

3. Zhu, X.; Yang, Q.; Wang, F.; Ma, D. Grain Orientation Optimization of Two-Dimensional Grain Selector during Directional Solidification of Ni-Based Superalloys. Materials 2020, 13, 1121. [CrossRef] [PubMed]

4. Kiruthika, P.; Makineni, S.K.; Srivastava, C. Growth mechanism of the interdiffusion zone between platinum modified bond coats and single crystal superalloys. Acta Mater. 2016, 105, 438-448. [CrossRef]

5. Segersäll, M.; Moverare, J.J. Crystallographic Orientation Influence on the Serrated Yielding Behavior of a Single-Crystal Superalloy. Materials 2013, 6, 437-444. [CrossRef] [PubMed]

6. Tan, X.P.; Hong, H.U.; Choi, B.G. Characterization of topologically close-packed phases in secondary reaction zone in a coated CMSX-4 single crystal Ni-based superalloy. J. Mater. Sci. 2013, 48, 1085-1089. [CrossRef]

7. Yang, Y.F.; Jiang, C.Y.; Bao, Z.B. Effect of aluminisation characteristics on the microstructure of single phase $\beta$-(Ni,Pt)Al coating and the isothermal oxidation behaviour. Corros. Sci. 2016, 111, 162-174. [CrossRef]

8. Yang, H.Z.; Zou, J.P.; Shi, Q. Analysis of the microstructural evolution and interface diffusion behavior of NiCoCrAlYTa coating in high temperature oxidation. Corros. Sci. 2019, 153, 162-169. [CrossRef]

9. Guo, C.; Wen, W.; Cheng, Y.X.; Zhu, S.L.; Wang, F.H. Yttria partially stabilised zirconia as diffusion barrier between NiCrAlY and Ni-base single crystal René N5 superalloy. Corros. Sci. 2015, 94, 122-128. [CrossRef]

10. Qin, C.; Xu, H.; Zhou, Z.; He, Y.; Lu, C.; Gao, K.; Zheng, W.; Yang, J.; Wang, D.; Sun, Y.; et al. Microstructure and Mechanical Performance of the DD98M-DD98M Single Crystal Superalloy Joints Brazed Using a Pd-Si Composite Filler. Metals 2019, 9, 1001. [CrossRef] 
11. Murakami, H.; Sakai, T. Anisotropy of secondary reaction zone formation in aluminized Ni-based single-crystal superalloys. Scr. Mater. 2008, 59, 428-431. [CrossRef]

12. Taylor, T.A.; Walsh, P.N. Thermal expansion of MCrAlY alloys. Surf. Coat. Technol. 2004, 177, $24-31$. [CrossRef]

13. Wang, J.L.; Chen, M.H.; Yang, L.L.; Zhu, S.L.; Wang, F.H. Comparative study of oxidation and interdiffusion behavior of AIP NiCrAlY and sputtered nanocrystalline coatings on a nickel-based single-crystal superalloy. Corros. Sci. 2015, 98, 530-540. [CrossRef]

14. Yuan, K.; Eriksson, R.; Peng, R.L. MCrAlY coating design based on oxidation-diffusion modelling. Part I: Microstructural evolution. Surf. Coat. Technol. 2014, 254, 79-96. [CrossRef]

15. Wang, X.Y.; Wen, Z.X.; Cheng, H.; Gu, S.N.; Lu, G.X. Influences of the Heating and Cooling Rates on the Dissolution and Precipitation Behavior of a Nickel-Based Single-Crystal Superalloy. Metals 2019, 9, 360. [CrossRef]

16. Hou, P.Y. Segregation phenomena at thermally grown Al2O3/alloy interfaces. Ann. Rev. Mater. Res. 2008, 38, 275-298. [CrossRef]

17. Hou, S.J.; Zhu, S.L.; Zhang, T.; Wang, F.H. A magnetron sputtered microcrystalline $\beta$-NiAl coating for SC superalloys. Part I. Characterization and comparison of isothermal oxidation behavior at $1100{ }^{\circ} \mathrm{C}$ with a NiCrAlY coating. Appl. Surf. Sci. 2015, 324, 1-12. [CrossRef]

18. Zagula, M. Oxidation Behavior of Non-Modified and Rhodium-or Palladium-Modified Aluminide Coatings Deposited on CMSX-4 Superalloy. Metals 2018, 8, 613. [CrossRef]

19. Zhang, P.M. Long-term oxidation of MCrAlY coatings at $1000{ }^{\circ} \mathrm{C}$ and an Al-activity based coating life criterion. Surf. Coat. Technol. 2017, 332, 12-21. [CrossRef]

20. Detrois, M.; Antonov, S.; Randolph, C. Helmink. Precipitate phase stability in $\gamma-\gamma^{\prime}-\delta-\eta$ Ni-Base superalloys. JOM 2014, 66, 2478-2485. [CrossRef]

21. Fan, Z.; Duan, W.; Zhang, X.; Mei, X.; Wang, W.; Cui, J. Influence of Preheating on the Microstructure Evolution of Laser Re-Melting Thermal Barrier Coatings/Ni-Based Single Crystal Superalloy Multilayer System. Materials 2019, 12, 3088. [CrossRef] [PubMed]

22. Shi, J.; Li, H.Q.; Wan, M.Q.; Wang, H.L.; Wang, X. High temperature oxidation and inter-diffusion behavior of electroplated Ni-Re diffusion barriers between NiCoCrAlY coating and orthorhombic-Ti 2 AlNb alloy. Corros. Sci. 2016, 102, 200-208. [CrossRef]

23. Valíček, J.; Harničárová, M.; Řehoř, J.; Kušnerová, M.; Gombár, M.; Drbúl, M.; Šajgalík, M.; Filipenský, J.; Fulemová, J.; Vagaská, A. Prediction of Cutting Parameters of HVOF-Sprayed Stellite 6. Appl. Sci. 2020, 10, 2524. [CrossRef]

24. Fernández-Abia, A.I.; Barreiro, J.; López-Lacalle, L.N. Behavior of austenitic stainless steels at high speed turning using specific force coefficients. Int. J. Adv. Manuf. Technol. 2012, 62, 505-515. [CrossRef]

25. Fernández-Abia, A.I.; Barreiro, J.; López-Lacalle, L.N. The influence of cutting speed in austenitic stainless steel machining: Study of specific force coefficients. AIP Conf. Proc. 2012, 1431, 518-525. [CrossRef]

26. Rodríguez-Barrero, S.; Fernández-Larrinoa, J.; Azkona, I. Enhanced Performance of Nanostructured Coatings for Drilling by Droplet Elimination. Mater. Manuf. Proc. 2016, 31, 593-602. [CrossRef]

27. Pillai, R.; Wessel, E.; Nowak, W.J. Predicting Effect of Base Alloy Composition on Oxidation and Interdiffusion-Induced Degradation of an MCrAlY Coating. JOM 2018, 70, 1520-1526. [CrossRef]

28. Zhang, N.; Zhang, N.N.; Guan, S. Composition versus Wear Behaviour of Air Plasma Sprayed NiCr-TiB $2-\mathrm{ZrB}_{2}$ Composite Coating. Coatings 2018, 8, 273. [CrossRef]

29. Zhou, S.; Lei, J.; Xiong, Z. Characteristics and properties of cryomilling-induced columnar growth in NiCrAlY coatings on Ni-based superalloy by laser induction hybrid cladding. J. Mater. Res. 2016, 31, 1338-1347. [CrossRef]

30. Fernández-Abia, A.I.; Barreiro, J.; Fernández-Larrinoa, J. Behaviour of PVD Coatings in the Turning of Austenitic Stainless Steels. Procedia Eng. 2013, 63, 133-141. [CrossRef]

31. Yang, L.L.; Chen, M.H.; Wang, J.L.; Qiao, Y.X.; Guo, P.Y.; Zhu, S.L.; Wang, F.H. Microstructure and composition evolution of a single-crystal superalloy caused by elements interdiffusion with an overlay NiCrAlY coating on oxidation. J. Mater. Sci. Technol. 2020, 45, 49-58. [CrossRef]

32. Dahl, K.V.; Hald, J.; Horsewell, A. Interdiffusion between Ni-Based superalloy and MCrAlY coating. Defect Diffus. Forum 2006, 258, 73-78. [CrossRef] 
33. Ta, N.; Zhang, L.J.; Du, Y. A Trial to Design $\gamma / \gamma^{\prime}$ Bond Coat in Ni-Al-Cr Mode TBCs Aided by Phase-Field Simulation. Coatings 2018, 8, 421. [CrossRef]

34. Yang, J.X.; Zheng, Q.; Sun, X.F. Topologically close-packed phase precipitation in a nickel-base superalloy during thermal exposure. Mater. Sci. Eng. 2007, 465, 100-108. [CrossRef]

35. Fan, Q.X.; Yu, H.J.; Wang, T.G.; Liu, Y.M. Microstructure and oxidation resistance of a Si doped platinum modified Aluminide coating deposited on a single crystal superalloy. Coatings 2018, 8, 264. [CrossRef]

36. Latief, F.H.; Kakehi, K. Influence of thermal exposure on the creep properties of an aluminized Ni-based single crystal superalloy in different surface orientations. Mater. Des. 2014, 56, 816-821. [CrossRef]

37. Reed, R.C.; Cox, D.C.; Rae, C.M.F. Damage accumulation during creep deformationof a single crystal superalloy at $1150{ }^{\circ}$ C. Mater. Sci. Eng. 2007, 448, 88-96. [CrossRef]

38. Liu, Y.Z.; Hu, X.B.; Zheng, S.J.; Zhu, Y.L.; Wei, H.; Ma, X.L. Microstructural evolution of the interface between NiCrAlY coating and superalloy during isothermal oxidation. Mater. Des. 2015, 80, 63-69. [CrossRef]

39. Eriksson, R.; Yuan, K.; Li, X.H. MCrAlY coating design based on oxidation-diffusion modelling. Part II: Lifing aspects. Surf. Coat. Technol. 2014, 253, 27-37. [CrossRef]

(C) 2020 by the authors. Licensee MDPI, Basel, Switzerland. This article is an open access article distributed under the terms and conditions of the Creative Commons Attribution (CC BY) license (http://creativecommons.org/licenses/by/4.0/). 